\title{
Maize productivity in succession to cover crops, nitrogen fertilization and inoculation with Azospirillum brasilense
}

\author{
Antônio C. dos Santos Júnior ${ }^{1}$, Marco A. C. de Carvalho ${ }^{1}$, Oscar M. Yamashita ${ }^{1}$, Tauan R. Tavanti² \& \\ Renan F. R. Tavanti ${ }^{2}$ \\ ${ }^{1}$ Universidade do Estado de Mato Grosso. Alta Floresta, MT, Brasil. E-mail: caladojunior@hotmail.com - ORCID: 0000-0003-3687-567X; marcocarvalho@unemat.br - \\ ORCID: 0000-0003-4966-1013; yama@unemat.br - ORCID: 0000-0001-6715-626X \\ ${ }^{2}$ Universidade Estadual Paulista “Júlio de Mesquita Filho". Ilha Solteira, SP. E-mail: tauanrt@outlook.com - ORCID: 0000-0001-6915-1702; renan.tavanti91@gmail.com \\ (Corresponding author) - ORCID: 0000-0002-4496-9660
}

\begin{abstract}
The use of microorganisms in agriculture such as Azospirillum brasilense and the cultivation of cover crops in the off season, together with nitrogen fertilization, may be interesting alternatives to increase crop yield. The objective of this study was to evaluate the growth, production and nitrogen concentration of maize grown in succession to cover crops and their interactions with A. brasilense inoculation and topdressing mineral $\mathrm{N}$ fertilization. The experiment was conducted on Oxisol, in randomized block design in split-splitplot scheme with four repetitions. The plots consisted of four cover crops: jackbean (Canavalia ensiformis), dwarf pigeon pea (Cajanus cajan), crotalaria (Crotalaria spectabilis) and spontaneous vegetation. In the subplots, with or without inoculation of $A$. brasilense in maize seeds, and in the sub-subplots: with or without topdressing $\mathrm{N}$ fertilization. It was verified that jackbean can generate increments of up to $8.3 \%$ in grains per ear, $6.9 \%$ in length of ear and $15.2 \%$ in mass of one hundred grains. Consequently, the grain yield was higher in this treatment (18\%). The inoculation with A. brasilense and topdressing $\mathrm{N}$ fertilization did not generate significant increments in maize production components, as observed for cover crops.
\end{abstract}

Key words: Zea mays L., diazotrophic bacteria, plant nutrition

\section{Produtividade de milho em sucessão a plantas de cobertura, adubação nitrogenada e inoculação com Azospirillum brasilense}

RESUMO: O uso de microrganismos na agricultura como Azospirillum brasilense e o cultivo de plantas de cobertura na entressafra, juntamente com a adubação nitrogenada, podem ser alternativas interessantes para aumentar a produtividade das culturas. Este estudo teve por objetivo avaliar os componentes de crescimento e de produção e o teor de nitrogênio do milho cultivado em sucessão ao cultivo de plantas de cobertura e suas interações com a inoculação de $A$. brasilense e a adubação mineral de $\mathrm{N}$ em cobertura. $\mathrm{O}$ experimento foi conduzido em Latossolo Vermelho-Amarelo no delineamento de blocos casualizados em parcelas subsubdivididas com quatro repetições. As parcelas foram constituídas por quatro plantas de cobertura: feijãode-porco (Canavalia ensiformis), feijão guandu anão (Cajanus cajan), crotalária (Crotalaria spectabilis) e vegetação espontânea. Nas subparcelas, com ou sem inoculação de A. brasilense nas sementes de milho e, nas sub-subparcelas: com ou sem adubação nitrogenada em cobertura. Verificou-se que o feijão-de-porco pode gerar incrementos de até $8,3 \%$ em grãos por espiga, 6,9\% em comprimento de espiga e 15,2\% em massa de cem grãos. Consequentemente, a produtividade de grãos foi maior neste tratamento (18\%). A inoculação com $A$. brasilense e a adubação nitrogenada em cobertura não geraram incrementos significativos nos componentes produtivos do milho, como observado para plantas de cobertura.

Palavras-chave: Zea mays L., bactérias diazotróficas, nutrição de plantas 


\section{INTRODUCTION}

In Brazil, 97.8 million tons of maize were produced in the $2017 / 18$ harvest, consolidating the country as the third largest producer in the world (CONAB, 2018). This condition is due to the increase in average productivity in the country, stimulated by the use of technologies such as: genetic improvement of cultivars, plant population density, nitrogen (N) doses and time, genetically modified materials and sowing methods (Chen \& Weil, 2011; Ning et al., 2012; Cruz et al., 2014; Bian et al., 2016; Shi et al., 2016; Eckert et al., 2017).

The use of microorganisms in agriculture, such as Azospirillum brasilense, and the cultivation of cover crops before the harvest of soybean and maize, have been interesting alternatives to increase grain yield and foliar $\mathrm{N}$ concentrations in crops (Aguiar et al., 2011; Cangahuala-Inocente et al., 2013; Galindo et al., 2018). Kappes et al. (2013) reported 9.4\% increase in grain yield of maize inoculated with $A$. brasilense, without topdressing $\mathrm{N}$ fertilization. Similarly, Albuquerque et al. (2013) found that the cultivation of Crotalaria spectabilis as cover crop in the off season was the best option for maize cultivation, generating yield increments up to $26 \%$.

Even with these results, few studies have reported the interactions involved in using $A$. brasilense to inoculate maize cultivated in succession to leguminous plants (green fertilizers) and topdressing $\mathrm{N}$ fertilization, mainly in ecotone regions such as the Cerrado-Amazon. The objective of this study was to evaluate the growth and production components and $\mathrm{N}$ concentrations in maize cultivated in succession to different cover crops and their interactions with the inoculation of $A$. brasilense and mineral $\mathrm{N}$ fertilization.

\section{Material ANd Methods}

The study was carried out in a farm located in the municipality of Guarantã do Norte, MT, Brazil, at $9^{\circ} 47^{\prime} 5.1^{\prime \prime}$ $\mathrm{W}$ and $54^{\circ} 57^{\prime} 50.9^{\prime \prime} \mathrm{S}$, at $270 \mathrm{~m}$ of altitude. The predominant climate in the region, according to the Köppen classification, is of Am type (tropical rainy) with well-defined seasons, dry in winter and rainy in summer. The mean annual temperature and precipitation are $26^{\circ} \mathrm{C}$ and $2400 \mathrm{~mm}$, respectively.

The soil of the site was as an Oxisol with clayey texture, having clay concentrations of $491 \mathrm{~g} \mathrm{~kg}^{-1}$, silt $104 \mathrm{~g} \mathrm{~kg}^{-1}$ and sand $405 \mathrm{~g} \mathrm{~kg}^{-1}$, determined by the pipette method EMBRAPA (2017). The initial chemical characteristics of the soil were: organic matter concentration of $11.2 \mathrm{~g} \mathrm{~kg}^{-1}, \mathrm{pH}$ in $\mathrm{CaCl}_{2}$ of 4.5, available $\mathrm{P}$ of $1.20 \mathrm{mg} \mathrm{dm}^{-3}$, exchangeable $\mathrm{K}$ of $25.9 \mathrm{mg} \mathrm{dm}^{-3}$, exchangeable $\mathrm{Ca}$ of $0.61 \mathrm{cmol}_{\mathrm{c}} \mathrm{dm}^{-3}$, exchangeable $\mathrm{Mg}$ of $0.29 \mathrm{cmol} \mathrm{dm}_{\mathrm{c}} \mathrm{dm}^{-3}$ exchangeable $\mathrm{Al}$ of $0.26 \mathrm{cmol}_{\mathrm{c}} \mathrm{dm}^{-3}$, cation exchange capacity of $6 \mathrm{cmol}_{c} \mathrm{dm}^{-3}$ and base saturation of $16 \%$, determined according to methodology proposed by EMBRAPA (2017).

The study area proceeds from a history of deforestation in the 2000, where trees of economic interest brought down subsequently, there was the burning of native vegetation. Then, pasture (Urochloa brizantha cv. Marandu) was planted for extensive livestock farming, which lasted until the installation of the experiment.
The preparation of the area began 60 days before the installation of the experiment, with application of dolomitic limestone (PRNT $=100 \%$ ), at a dose of $2720 \mathrm{~kg} \mathrm{ha}^{-1}$, for base saturation elevation at $60 \%$. Subsequently, the limestone was incorporated with heavy harrow, and another light harrow for ground leveling. On the occasion of sowing cover crops, corrective phosphorous fertilization was performed in the total area, using $200 \mathrm{~kg} \mathrm{ha}^{-1}$ of $\mathrm{P}_{2} \mathrm{O}_{5}$, incorporated in a depth of 0-0.10 $\mathrm{m}$, as recommended by Sousa \& Lobato (2004).

The randomized blocks design with split-split-plot scheme and four repetitions was used. In the plots, were evaluated the cover crops (green fertilizers): jackbean (Canavalia ensiformis), dwarf pigeon pea (Cajanus cajan), crotalaria (C. spectabilis) and spontaneous vegetation (S/V); in the subplots, with or without inoculation of $A$. brasilense in maize seeds, and in the subsubplots: with or without topdressing $\mathrm{N}$ fertilization, in maize vegetative stage $\mathrm{V} 5$, with $100 \mathrm{~kg} \mathrm{ha}^{-1}$ of $\mathrm{N}$, having as source ammonium sulfate $(20 \%$ of $\mathrm{N})$. The dimension of the plots was $10 \times 5 \mathrm{~m}$, subplots $5 \times 5 \mathrm{~m}$ and, sub-subplots of $5 \times 2.5 \mathrm{~m}$.

Cover plants were sown using a spacing of $0.50 \mathrm{~m}$ between rows and, respectively, 6 seeds of $C$. ensiformis $\mathrm{m}^{-1}\left(100 \mathrm{~kg} \mathrm{ha}^{-1}\right)$, 15 seeds of C. cajan $\mathrm{m}^{-1}\left(15 \mathrm{~kg} \mathrm{ha}^{-1}\right)$ and 30 seeds of $C$. spectabilis $\mathrm{m}^{-1}\left(40 \mathrm{~kg} \mathrm{ha}^{-1}\right)$. After 65 days of cover plant sowing, the period preceding the full flowering of the cover crops, manual weeding was performed, keeping the cut plants on the surface of the soil, for straw formation. Then, maize (Hybrid 2B512 from Dow Agrosciences ${ }^{\oplus}$ ) was sown in no-tillage system, with spacing of $0.50 \mathrm{~m}$ between rows and population density of 60000 plants $\mathrm{ha}^{-1}$. The basal fertilization carried out at the time of sowing maize was $300 \mathrm{~kg} \mathrm{ha}^{-1}$ with formulation $08-26-16$. The inoculation of seeds with $A$. brasilense, using the commercial product Azototal ${ }^{\oplus}$, according to treatments, was performed at dose of $0.5 \mathrm{~mL} \mathrm{~kg}^{-1}$ of seeds.

Weed control was performed manually by weeding at 20 days after sowing. There was no need for the application of pesticides for pest control, due to the low incidence observed.

For the monitoring of climatic conditions, data from the meteorological station of the neighboring municipality of Matupá, INMET- Instituto Nacional de Meteorologia (Figure 1) were used.

At 60 days after sowing the cover crops, the plants contained in $1.0 \mathrm{~m}$ of the central rows of the sub-subplots were collected. For spontaneous vegetation, plants contained in $0.25 \mathrm{~m}^{2}$ were randomly collected in three points. Thus, cover crops shoot fresh weight $\left(\mathrm{t} \mathrm{ha}^{-1}\right)$ was determined, and dry weight $\left(\mathrm{t} \mathrm{ha} \mathrm{C}^{-1}\right)$ after drying in an oven at $65^{\circ} \mathrm{C}$ until it reaches constant weight. The shoot dry matter of the cover crops was subsequently crushed in Willey mill, to determine the $\mathrm{N}$ concentration $\left(\mathrm{g} \mathrm{kg}^{-1}\right)$, according to the methodology proposed by Malavolta et al. (1997). The total $\mathrm{N}$ accumulation in the dry matter was also calculated for the cover crops, with the data transformed into $\mathrm{kg} \mathrm{ha}^{-1}$.

To determine the growth variables of maize in the flowering period, all the plants contained in $3 \mathrm{~m}$ of the three central rows of each experimental unit were collected. Thus, the plant height $(\mathrm{cm})$, ear insertion height $(\mathrm{cm})$ and stem diameter $(\mathrm{mm})$ were determined, with the aid of a tape measure. At the same time, the diagnosis leaves of maize (leaf opposite to the ear) were 


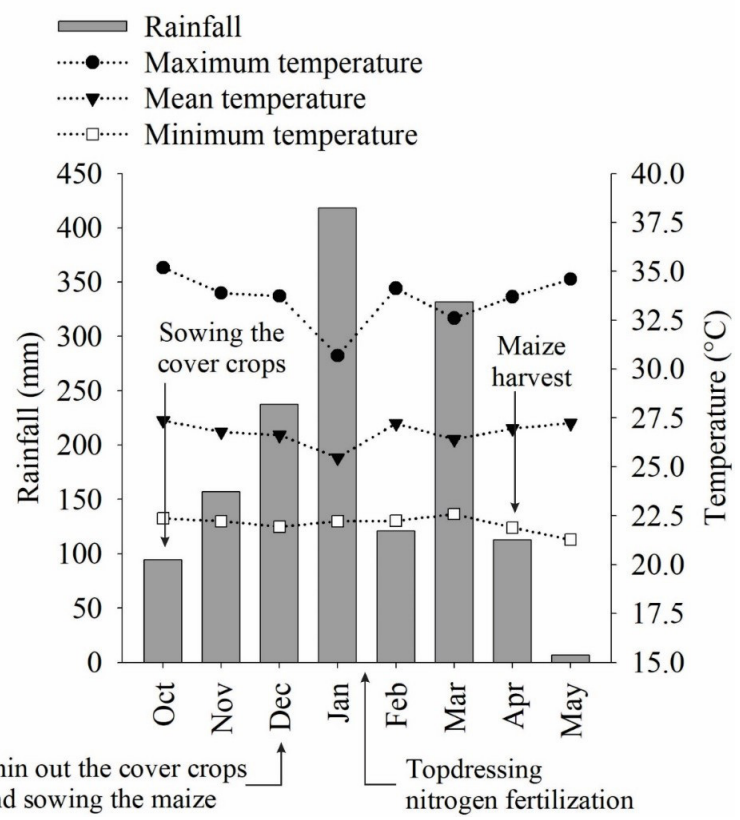

Data from the INMET meteorological station - Matupá, MT, Brazil (approximately 20 $\mathrm{km}$ from the study site)

Figure 1. Rainfall, maximum, minimum and average temperature during the cycle of cover crops and maize cultivated in a Latossolo Vermelho-Amarelo Distrófico

collected at the time when $50 \%$ of the plants in the area emitted the tassel, to determine the leaf $\mathrm{N}$ concentration, following the methodology described previously for cover crops. After the physiological maturity period of the grains, the productive components of maize were determined: number of grain rows in ear (n), number of grains per ear (n), ear length $(\mathrm{cm})$, mass of one hundred grains $(\mathrm{g})$ and grain yield $\left(\mathrm{kg} \mathrm{ha}^{-1}\right)$, with humidity (moisture) values adjusted to $13 \%$ on wet basis.

The data collected were submitted to the Shapiro \& Wilk normality test at $5 \%$ significance $(\mathrm{p}>0.05)$. In the presence of outliers, those with values 2.5 times greater than the interquartile interval were removed, respecting the limit of $10 \%$ of the total observations of each treatment. Subsequently, the normal data were subjected to analysis of variance by the $\mathrm{F}$ test $(\mathrm{p}<0.05)$ and, when significant, the means were compared by the Tukey test at $\mathrm{p}<0.05$.

\section{Results AND Discussion}

Regarding the cover crops cultivated during the off season period, differences were observed between the treatments for the accumulation of shoot dry matter and shoot fresh matter, $\mathrm{N}$ concentration and total $\mathrm{N}$ accumulation of the shoot cover crops (Figures 2A, B, C, D). Jackbean (C. ensiformis) was the best option among all the plants tested, with accumulations of shoot dry matter and total $\mathrm{N}$ accumulation of $6.52 \mathrm{t} \mathrm{ha}^{-1}$ and $185 \mathrm{~kg} \mathrm{ha}^{-1}$, respectively. Subsequently, the pigeon pea (C. cajan) and crotalaria (C. spectabilis), did not differ among themselves and presented shoot dry matter between 5.0 and $4.0 \mathrm{tha}^{-1}$ and total $\mathrm{N}$ accumulation between 101 and $94 \mathrm{~kg} \mathrm{ha}^{-1}$, respectively.

The area kept fallow under spontaneous vegetation presented as a disadvantageous option for shoot dry matter accumulation, being below $1.73 \mathrm{t} \mathrm{ha}^{-1}$ and total $\mathrm{N}$ accumulation below $48 \mathrm{~kg} \mathrm{ha}^{-1}$ (Figures 2A, D).

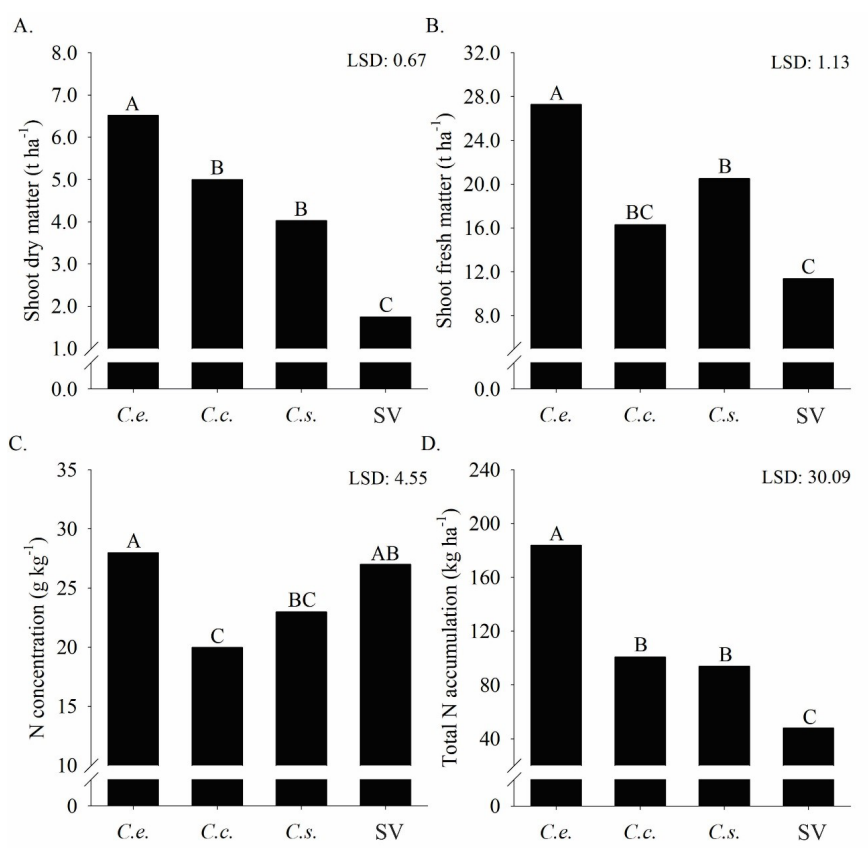

Means followed by the same letter do not differ statistically by the Tukey test at $\mathrm{p} \leq 0.05$; LSD: Corresponds to the least significant difference

Figure 2. Means of (A) shoot dry matter, (B) fresh matter, (C) nitrogen concentration and (D) total nitrogen accumulation of the cover crops: Canavalia ensiformis (C.e.), Cajanus Cajan (C.c), Crotalaria spectabilis (C.s.) and spontaneous vegetation (SV)

The growth variables of maize, plant height, ear insertion height and stem diameter showed no difference in the treatments with inoculation of $A$. brasilense and mineral fertilization of $\mathrm{N}$. However, cover crop cultivation in the off season provided increments for these variables, with the jackbean (C. ensiformis) being the best option for increasing maize ear insertion height and stem diameter, by $78 \mathrm{~cm}$ and $13 \mathrm{~mm}$, respectively (Figures 3B, C). Maize cultivated in succession to jackbean (C. ensiformis) or pigeon pea (C. cajan) was not different in terms of plant height, with 169 and 163 $\mathrm{cm}$, respectively (Figure $3 \mathrm{~A}$ ).

Maize plant height and ear insertion height were lower when grown in spontaneous vegetation area, with 159 and $67 \mathrm{~cm}$, respectively (Figures 3A, B). However, no difference was observed for maize stem diameter in the treatments in which the spontaneous vegetation, pigeon pea (C. cajan) and crotalaria (C. spectabilis) were cultivated in the off season, presenting $12 \mathrm{~mm}$ in the respective treatments (Figura 3C).

The interaction of these factors was significant for the plant height (Table 1). When maize was inoculated with $A$. brasilense and fertilized with mineral $\mathrm{N}$, it presented the smallest plant height $(159 \mathrm{~cm})$ in comparison to maize only fertilized with $\mathrm{N}(165 \mathrm{~cm})$.

The practice of inoculation of A. brasilense in annual grasses, may have affected its processes when $\mathrm{N}$ fertilization (ammonium sulfate source) was performed. According to Silva et al. (2007), this associative process is interrupted in the nitrogenase complex, perhaps due to the decrease in the supply of carbohydrates to microorganisms by maize plants. Therefore, the plants started using only the available $\mathrm{N}$, thus ending this association. Other authors, e.g., Arsene et al. (1996) and Hartmann \& Burris (1987) reported that $A$. brasilense fixes $\mathrm{N}$ under aerobic conditions, that 


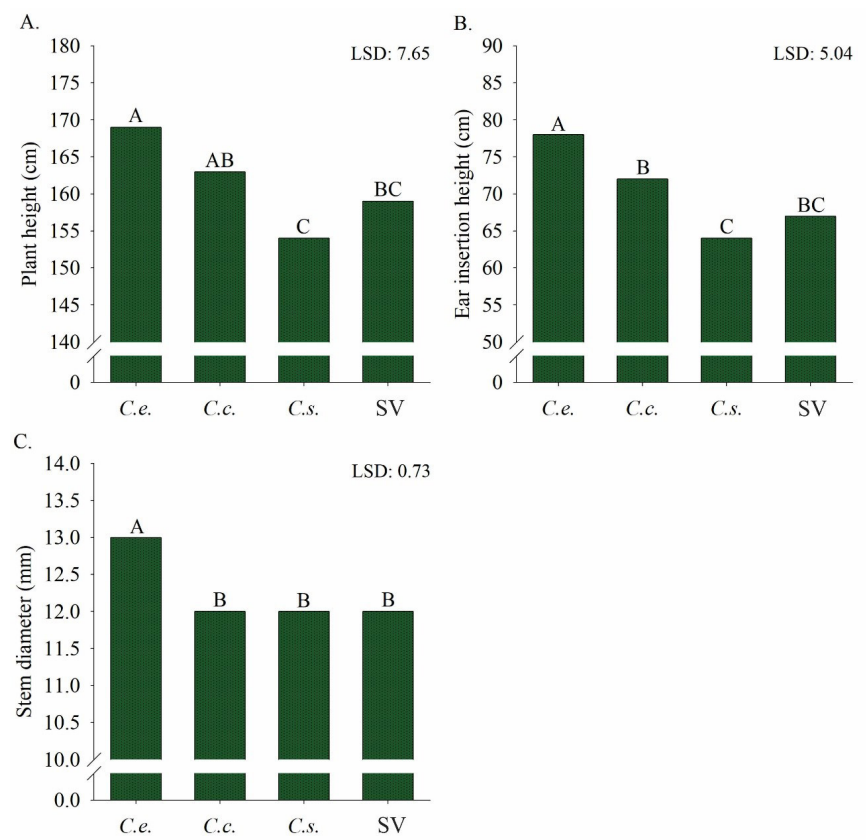

Means followed by the same letter do not differ statistically by the Tukey test at $\mathrm{p} \leq 0.05$; LSD: corresponds to the least significant difference

Figure 3. Means of (A) plant height, (B) ear insertion height and $(\mathrm{C})$ stem diameter of maize grown in succession to cover crops Canavalia ensiformis (C.e.), Cajanus cajan (C.c.), Crotalaria spectabilis (C.s.) and spontaneous vegetation (SV)

Table 1. Interaction effects between nitrogen fertilization and Azospirillum brasilense inoculation for maize plant height

\begin{tabular}{|c|c|c|}
\hline \multirow[b]{2}{*}{$\begin{array}{l}\text { Nitrogen } \\
\text { fertilization }\end{array}$} & \multicolumn{2}{|c|}{ Azospirillum brasilense } \\
\hline & $\begin{array}{c}\text { With } \\
\text { inoculation }\end{array}$ & $\begin{array}{c}\text { Without } \\
\text { inoculation }\end{array}$ \\
\hline & \multicolumn{2}{|c|}{ Plant height (cm) } \\
\hline With nitrogen fertilization & $159 \mathrm{aB}$ & $165 \mathrm{aA}$ \\
\hline Without nitrogen fertilization & $163 \mathrm{aA}$ & $158 \mathrm{bA}$ \\
\hline
\end{tabular}

Means followed by the same lowercase letter in the columns and uppercase in the row do not differ statistically by the Tukey test at $\mathrm{p} \leq 0.05$

is, in ammonium-depleted media. This bacterium also regulates nitrogenase activity through a shutdown mechanism described for photosynthetic bacteria. This mechanism corresponds to iron-protein $\mathrm{ADP}$ ribosylation in response to the environmental changes caused by ammonium concentration. Thus, it is assumed that in this study, A. brasilense had its processes affected by the activity of the enzyme nitrogenase in the presence of readily available ammonium.

Considering the yield components of maize, number of grain rows in ear, ear length, number of grains per ear, mass of one hundred grains, yield and foliar $\mathrm{N}$ concentration, there was no difference regarding the treatments with and without inoculation of $A$. brasilense. However, there was response of the number of grain rows in ear to treatments with and without topdressing $\mathrm{N}$ fertilization (Figure 4 ). When maize was fertilized with mineral $\mathrm{N}$, it presented the highest number of grain rows in ear (17), compared to non-fertilized maize (16).

In relation to the cultivation of cover crops in the off season, the jackbean (C. ensiformis) stood out in relation to the productive components inherent to the maize ear. In this system, there were increments of up to $8.3 \%$ in number of grains per ear, $6.9 \%$ in ear length and $15.2 \%$ in grain mass,

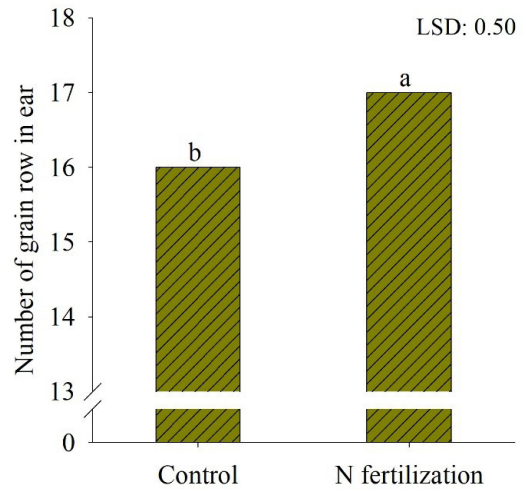

Means followed by the same letter do not differ statistically by the Tukey test at $\mathrm{p} \leq 0.05$; LSD: corresponds to the least significant difference

Figure 4. Means of number of grain rows in ear of maize grown with or without top-dressing nitrogen fertilization $\left(100 \mathrm{~kg} \mathrm{~N} \mathrm{ha}^{-1}\right.$ of ammonium sulphate)

when compared to maize cultivated in the spontaneous vegetation area (Figures 5B, C, D). Number of grain rows in ear, ear length and number of grains per ear, when maize was cultivated in succession to pigeon pea (C. cajan) did not differ
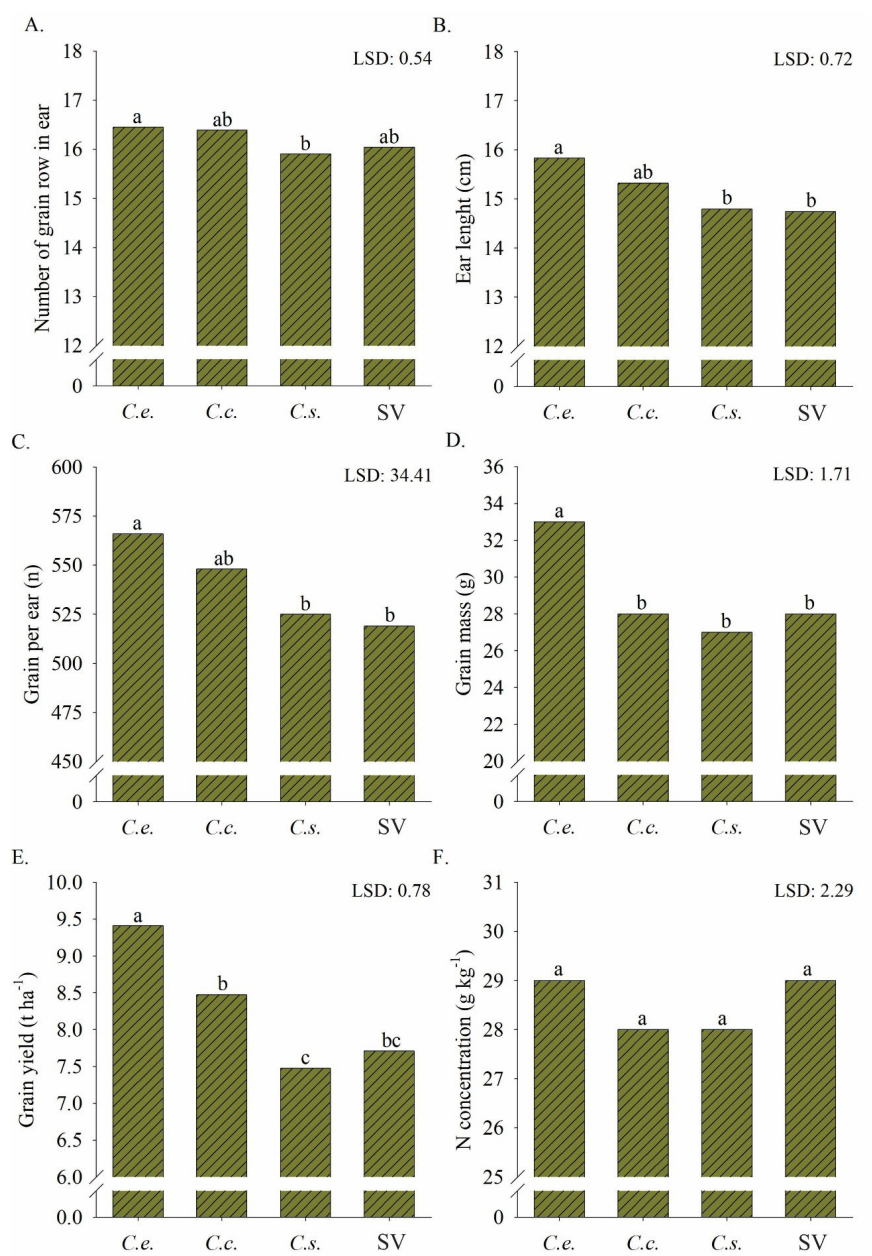

Means followed by the same letter do not differ statistically by the Tukey test at 0.05 ; LSD: corresponds to the least significant difference

Figure 5. Means of (A) number of grain rows in ear, (B) ear length, (C) number of grains per ear, (D) grain mass, (E) grain yield and ( $\mathrm{F}$ ) foliar $\mathrm{N}$ concentration of maize grown in succession to the cover crops Canavalia ensiformis (C.e.), Cajanus cajan (C.c), Crotalaria spectabilis (C.s.) and spontaneous vegetation (SV) 
from jackbean (C. ensiformis) (Figures 5A, B, C). However, they did not present the same yields for grain mass (28 and $33 \mathrm{~g}$, respectively). Ear length, number of grains per ear and grain mass also did not differ if the maize had been cultivated in succession to crotalaria (C. spectabilis) or spontaneous vegetation area. The obtained results point to a positive influence of jackbean on the productive components of maize. This fact can be justified by the higher production of shoot dry matter and shoot fresh matter, leaf $\mathrm{N}$ concentration and total accumulation of $\mathrm{N}$ of the jackbean in relation to the other cover crops, as previously presented (Figures 2A, B, C, D).

In relation to maize grain yield, the jackbean (C. ensiformis) provided productivity of up to $9.41 \mathrm{t} \mathrm{ha}^{-1}$, being superior to the other cover crops. Pigeon pea (C. cajan), crotalaria ( $C$. spectabilis) and spontaneous vegetation area (SV) presented 8.47, 7.48 and $7.71 \mathrm{t} \mathrm{ha}^{-1}$, respectively (Figure 5E). Similar results were reported by Santos et al. (2010), in which $C$. spectabilis and $C$. ensiformis cultivation positively influenced the vegetative and productive characteristics of maize crop, even in the absence of mineral $\mathrm{N}$ fertilization.

The inoculation of maize seeds with A. brasilense, under the conditions in which the experiment was carried out, did not provide significant increments in the maize production components, mainly in grain yield and foliar $\mathrm{N}$ concentration, with 8.34 tons ha-1 and $28 \mathrm{~g} \mathrm{~kg}^{-1}$ for grain yield and leaf $\mathrm{N}$ concentrations, respectively, in the treatments with inoculation and, respectively, $8.19 \mathrm{t} \mathrm{ha}^{-1}$ and $29 \mathrm{~g} \mathrm{~kg}^{-1}$, without inoculation. Some authors have emphasized that the efficiency of the bacterium under study is linked to several factors, such as the selection of appropriate strains and cultivation conditions (Radwan et al., 2004). Regarding the conditions of cultivation, it is suggested that soil acidity, organic matter content, C:N ratio of the straw of previous crops and availability of mineral $\mathrm{N}$ are the soil attributes that most influence the survival and interactions of microorganism with plants (Bartchechen et al., 2010). Thus, it is assumed that soil fertility conditions were not fully adequate for the survival and/or effective action of A. brasilense. In addition, the cover crops chosen in this study presented a low $\mathrm{C}: \mathrm{N}$ ratio, and the topdressing fertilization with ammonium sulphate ( $\left.100 \mathrm{~kg} \mathrm{~N} \mathrm{ha}^{-1}\right)$, possibly impaired the biological fixation process, as discussed previously. Another point to consider is the affinity of the microorganism with the genotype or cultivated maize hybrid (Hybrid 2B512), in which it is assumed that the inoculation of different strains of $A$. brasilense could provide different responses in the biometric, productive and foliar $\mathrm{N}$ concentration in maize.

Similar to the inoculation treatments with A. brasilense, the mineral $\mathrm{N}$ fertilization did not provide increments in the productive components and foliar $\mathrm{N}$ concentrations of maize. Contrasting results were observed by Albuquerque et al. (2013), who observed increase in grain yield of maize cultivated in succession to C. spectabilis and fertilized with $80 \mathrm{~kg} \mathrm{~N} \mathrm{ha}^{-1}$ in the urea source. It was assumed that the lack of response of maize to the $\mathrm{N}$ applied in topdressing is not dependent on the source of $\mathrm{N}$, but rather to the edaphoclimatic conditions for the realization of this study. Lacerda et al. (2015) indicate the need to reevaluate the management of fertilization in the agricultural system, even in soils with built fertility, to reconcile the increase of crop productivity with the more efficient use of fertilizers, aiming at greater profitability for the rural producer.

\section{Conclusions}

1. The jackbean (C. ensiformis) obtained higher accumulation of shoot fresh matter and shoot dry matter, as well as a higher nitrogen concentration and accumulation.

2. The jackbean is the best option among the cover crops tested in the off season period for maize cultivation, because it generates the highest values in the growth and production components of maize.

3. The inoculation of maize seeds with Azospirillum brasilense and the topdressing $\mathrm{N}$ fertilization of $100 \mathrm{~kg} \mathrm{ha}^{-1}$ (ammonium sulphate source) did not favor the growth and production components of maize in the first year of cultivation.

\section{Literature Cited}

Aguiar, A. D. C. F.; Freitas, I. C. de; Carvalho, C. S.; Monroe, P. H. M.; Moura, E. G. de. Efficiency of an agrosystem designed for family farming in the pre-Amazon region. Renewable Agriculture and Food Systems, v.26, p.24-30, 2011. https://doi.org/10.1017/ S1742170510000396

Albuquerque, A. W.; Santos, J. R.; Reis, L. S. Plantas de cobertura e adubação nitrogenada na produção de milho em sistema de plantio direto. Revista Brasileira de Engenharia Agrícola e Ambiental, v.17, p.721-726, 2013. https://doi.org/10.1590/S141543662013000700005

Arsene, F.; Kaminski, P.A.; Elmerich, C. Modulation of NifA activity by PII in Azospirillum brasilense: Evidence for a regulatory role of the NifA N-terminal domain. Journal of Bacteriology, v.178, p.48304838, 1996. https://doi.org/10.1128/jb.178.16.4830-4838.1996

Bartchechen, A.; Fiori C. C. L.; Watanabe S. H.; Guarido R. C. Efeito da inoculação de Azospirillum brasilense na produtividade da cultura do milho (Zea mays L.). Campo Digital, v.5, p.56-59, 2010.

Bian, D.; Jia, G.; Cai, L.; Ma, Z.; Eneji, A. E.; Cui, Y. Effects of tillage practices on root characteristics and root lodging resistance of maize. Field Crops Research, v.185, p.89-96, 2016. https://doi. org/10.1016/j.fcr.2015.10.008

Cangahuala-Inocente, G. C.; Amaral, F. P. do; Faleiro, A. C.; Huergo, L. F.; Arisi, A. C. M. Identification of six differentially accumulated proteins of Zea mays seedlings (DKB240 variety) inoculated with Azospirillum brasilense strain FP2. European Journal of Soil Biology, v.58, p.45-50, 2013. https://doi.org/10.1016/j.ejsobi.2013.06.002

Chen, G.; Weil, R. R. Root growth and yield of maize as affected by soil compaction and cover crops. Soil and Tillage Research, v.117, p.17-27, 2011. https://doi.org/10.1016/j.still.2011.08.001

CONAB - Companhia Nacional de Abastecimento. $6^{\circ}$ Levantamento - Safra 2017/18 - Grãos. Available on: <http://www.conab.gov. br/OlalaCMS/uploads/arquivos/18_03_13_14_15_33_grao_ marco_2018.pdf >. Accessed on: Mar. 2018.

Cruz, J. C.; Pereira Filho, I. A.; Simão, E. D. P. 478 cultivares de milho estão disponíveis no mercado de sementes do Brasil para a safra 2014/2015. Sete Lagoas: Embrapa Milho e Sorgo, 2014. 35p.

Eckert, C. T.; Frigo, E. P.; Albrecht, L. P.; Albrecht, A. J. P.; Christ, D.; Santos, W. G.; Berkembrock, E.; Egewarth, V. A. Maize ethanol production in Brazil: Characteristics and perspectives. Renewable and Sustainable Energy Reviews, v.83, p.3907-3912, 2017. https:// doi.org/10.1016/j.rser.2017.10.082 
EMBRAPA - Empresa Brasileira de Pesquisa Agropecuária. Manual de métodos de análise de solo. 2017. Available on: <https://www. embrapa.br/busca-de-publicacoes/-/publicacao/1085209/manualde-metodos-de-analise-de-solo>. Accessed on: Mar. 2018.

EMBRAPA - Empresa Brasileira de Pesquisa Agropecuária. Brazilian soil classification system. 2018. Available on: <https://www. embrapa.br/busca-de-publicacoes/-/publicacao/1094001/ brazilian-soil-classification-system> Accessed on: Mar. 2018.

Galindo, F. S.; Teixeira Filho, M. M.; Buzetti, S.; Ludkiewicz, M. G.; Rosa, P. A.; Tritapepe, C. A. Technical and economic viability of co-inoculation with Azospirillum brasilense in soybean cultivars in the Cerrado. Revista Brasileira de Engenharia Agrícola e Ambiental, v.22, p.51-56, 2018. https://doi.org/10.1590/18071929/agriambi.v22n1p51-56

Hartmann, A.N.T.O.N.; Burris, R.H. Regulation of nitrogenase activity by oxygen in Azospirillum brasilense and Azospirillum lipoferum. Journal of bacteriology, v.169, p.944-948, 1987. https:// doi.org/10.1128/jb.169.3.944-948.1987

Kappes, C.; Arf, O.; Arf, M. V.; Ferreira, J. P.; Bem, E. A. dal; Portugal, J. R.; Gonçalves Vilela, R. Inoculação de sementes com bactéria diasotróficas e aplicação de nitrogênio em cobertura e foliar em milho. Semina: Ciências Agrárias, v.34, p.527-538, 2013. https:// doi.org/10.5433/1679-0359.2013v34n2p527

Lacerda, J. J. J; Resende, Á. V.; Neto, A. E. F.; Hickmann, C.; Conceição, O. P. Adubação, produtividade e rentabilidade da rotação entre soja e milho em solo com fertilidade construída. Pesquisa Agropecuária Brasileira, v.50, p.769-778, 2015. https:// doi.org/10.1590/S0100-204X2015000900005
Malavolta, E.; Vitti, G. C.; Oliveira, S. A. Avaliação do estado nutricional de plantas: Princípios e aplicações. 2.ed. Piracicaba: Potafós, 1997. 319p.

Ning, T.; Zheng, Y.; Han, H.; Jiang, G.; Li, Z. Nitrogen uptake, biomass yield and quality of intercropped spring-and summer-sown maize at different nitrogen levels in the North China Plain. Biomass and Bioenergy, v.47, p.91-98, 2012. https://doi.org/10.1016/j. biombioe.2012.09.059

Radwan, T. E. S. E. D.; Mohamed, Z. K.; Reis, V. M. Effect of inoculation with Azospirillum and Herbaspirillum on production of indolic compounds and growth of wheat and rice seedlings. Pesquisa Agropecuária Brasileira, v.39, p.987-994, 2004. https:// doi.org/10.1590/S0100-204X2004001000006

Santos, P. A.; Silva, A. F.; Carvalho, M. A. C.; Caione, G. Adubos verdes e adubação nitrogenada em cobertura no cultivo do milho. Revista Brasileira de Milho e Sorgo, v.9, p.123-134, 2010. https:// doi.org/10.18512/1980-6477/rbms.v9n2p123-134

Shi, D. Y.; Li, Y. H.; Zhang, J. W.; Peng, L. I. U.; Bin, Z.; Dong, S. T. Increased plant density and reduced $\mathrm{N}$ rate lead to more grain yield and higher resource utilization in summer maize. Journal of Integrative Agriculture, v.15, p.2515-2528, 2016. https://doi. org/10.1016/S2095-3119(16)61355-2

Silva, D. M.; Antoniolli, Z. I.; Jacques, R. J. S.; Voss, M. Bactérias diasotróficas nas folhas e colmos de plantas de arroz irrigado (Oryza sativa L.). Revista Brasileira de Agrociência, v.13, p.181187, 2007.

Sousa, D. D.; Lobato, E. Cerrado: Correção do solo e adubação. 2.ed. Planaltina: Embrapa Cerrados, 2004. 420p. 